\title{
3. COMPARATIVE AND GLOBAL POLICY STUDIES ON ADULT EDUCATION
}

\author{
Key Patterns in Contemporary Adult Education Policy Research
}

\section{INTRODUCTION}

This chapter discusses the type of knowledge that comparative and global policy studies on adult education contributes to adult education research broadly conceived. ${ }^{1}$

Comprehending transformations in adult education today requires us to look beyond and across the national scale if we are to comprehend continuities and changes in adult education policy, practice and research.

Fittingly, regional and global cartographic and mapping exercises are receiving serious attention on both sides of the Atlantic Ocean (Nylander \& Fejes, 2019; Fejes \& Wildemeersch, 2015; Milana, Webb, Holford, Waller, \& Jarvis, 2018; Knox, Conceição, \& Martin, 2017). But mapping change and continuities in adult education research also calls for meta-investigations on what sort of knowledge the varied traditions of adult education research have contributed to the field, and how new distinctive bodies of work emerge from collaboration and cross-fertilization among research traditions.

Adult education researchers increasingly make reference to policy changes that happen at local, national, European or global levels when describing the background of, or context for, a study in adult education (see, among others: Waller at al., 2014, 2015; Hinton-Smith, 2012; Bartlett, Rees, \& Watts, 2000). But policy research specifically research of policy (Desjardins \& Rubenson, 2009) is something different. It is research that makes policy its object of inquiry, and examines how policy contributes to change and continuities in the formation of ideas and concepts about adult education, and in adult education practice.

However, a good deal of policy research must be critically assessed as it (still) assumes the nation-state as its main unit of analysis, for instance, to appraise the implementation of a governmental policy, and its effects on delivery systems (adult education, higher education, etc.) and/or in a locale (a city, a county, etc.). Other studies compare countries to identify and explain similarities and differences in national policy developments and implementations, through large-scale surveys on adults' participation (e.g. the Adult Education Survey, AES), or adult's skills (e.g. the Programme for International Assessment of Adult Skills, PIAAC). This strand of 
policy research builds on a conception of polity as a territorially based community, where a country or nation-state represents a unique, territorially-bound entity.

However, policy research has increasingly assumed also a multi-scalar or global perspective, which acknowledges that a polity may include also non-territoriallybound political entities or communities that, despite their territorial localizations are "oriented towards the governance of a common "governance-object" (Corry 2010, p. 159). Elsewhere (Milana, 2012, 2015, 2017), I argue and demonstrate how adult education has been constructed as such a 'governance-object' by global, non-territorially bound polities (see also: Desjardins \& Rubenson, 2009; Nesbit \& Welton, 2013; Milana \& Holford, 2014; Milana \& Nesbit, 2015; Milana, Holford, \& Mohorčič Špolar, 2016). This distinctive construction, it is argued, effects the adult education sector, and particularly supply and demand (Milana \& Klatt, forthcoming) which depends on various factors and on which global governance also impinges. These include existing laws and regulations, available resources, the positioning of adult education providers in local, national and global education markets, and adults' perceptions of what provision is worth their time and money. Exemplary in this respect is the increased liberalization of the broader education market (Marginson, 1997) that brings about market competition among public and private providers to reach out to 'adults-as-customers'.

Hence, there is now a flourishing field of research on the work of intergovernmental organizations in legitimizing different political interests, through new international agendas, soft governance mechanisms and the promotion of monitoring culture in adult education (see among others: Milana, 2013; Panitsides, 2015; Ioannidou, 2007; Jacobi, 2009; Rubenson, 2015; Tett, 2014).

It is this body of work that I refer to in this chapter as comparative and global policy studies on adult education. In short, it comprises the comparative investigations of policy that pays attention to policy developments also at European and global scales, and their interactions with national and local policy developments.

In what follows, I describe the methodology employed to perform a metainvestigation (Sandelowski \& Barroso, 2007) of comparative and global policy studies on adult education, comprised of a set of fifty-eight academic texts, largely articles in international peer-reviewed journals published between 2000 and 2015. Then I present and discuss the four research patterns that emerged from the analysis. By pattern I mean a fairly coherent and intelligible configuration, which is limited to the texts under scrutiny, based on the combination of the main unit of analysis, and the specific research aims. Finally, I assess how these patterns are contributing to adult education research, and in so doing, to our understanding of change and continuities in adult education policy and practice.

\section{METHODOLOGY}

A meta-investigation is a process of rendering a set of academic publications the object of reflection and analysis. The analysis is neither causal nor exhaustive and 
has the purpose of prompting a documented reflection on the "connections between existing studies [...] [and] gaps and omissions in a given body of research [that] enables dialogue and debate" (Sandelowski \& Barroso, 2007, p. 3). The first step of a meta-investigation is the identification and selection of a relevant set of academic publications. I started by gathering a few familiar texts to me, then carried out systematic searches, using different combinations relevant keywords in libraries and online databases, among which ERIC (Education Resources Information Centre). I extended my search through the internal search engines of four journals: Adult Education Quarterly, International Journal of Lifelong Education, International Review of Education, Comparative Education which were chosen as they specialize in adult education and/or comparative education. Resulting from these searches, and the reading of abstracts, about two hundred texts were first selected initially; however, from a second reading of abstracts and full texts, I selected those that were pertinent to my scope. So, for instance, texts dealing with adult education policies in a given country, which did not adopt a comparative perspective or which did not connect to the work of intergovernmental organizations, were excluded from my data set.

The second step in a meta-investigation is the adoption of a strategy to analyze the data set. I used an inductive analytic strategy to synthesize the data so to generate inferences (Polkinghorne, 1983) that were "grounded in data and not speculative or abstract" (Schwandt, 2001, p. 125). Such an analytic strategy relies on the researcher's knowledge and understanding of the phenomenon under consideration.

Three research questions guided the meta-investigation: What are the main units of analysis, either explicit or implicit, in comparative and global policy studies on adult education? What do these studies aim at? Is it possible to identify (and distinguish between) one or more research patterns?

Procedurally, I employed a two-step strategy: First, I read each of the texts from my dataset and grouped them on the basis of observed similarities in terms of their main 'units of analysis'; then, I considered each of the study's aim and regrouped the texts in light of the study's aim alongside the unit of analysis (as outlined in results section).

\section{RESULTS}

Four intelligible research patterns emerged from the meta-investigation, as reported below. There are a group of studies which aim to increase our understanding of shifts in political ideologies and how they redefine the boundaries of adult education and learning provision (Pattern 1), but also change and continuities in discourses, agendas and actions that occur across geographical and/or geopolitical territories (Pattern 2). Moreover, there is a body of work that explicates the dynamic elements that compose specific systems of governance in adult education, and their effects on other systems (Pattern 3). Finally, drawing on existing evidence, they also problematize common political beliefs concerned with the education and learning of adults (Pattern 4). 


\section{Describing Changes and Evolutions along a Temporal Continuum (Pattern 1)}

The studies grouped under pattern 1 assume time as the primary unit of analysis and represent $20 \%$ of the total number of studies under consideration. Their main aim is to comprehend, explain, and critique changes in political ideologies that brought about perceptible shifts in discourses on, and around, the education and learning of adults. For the most part, these studies illustrate evolutions (and to some extent involutions) in policy discourses that occur at ideational level, but also the changes they produce at normative, administrative and/or financial levels. Such changes can be of a soft or drastic nature, and pertain to the norms and standards for the education and learning of adults (normative changes), the organization and control over education and learning opportunities (administrative changes), and the allocation of public and private resources to support these opportunities (financial changes). All of which redefines the boundaries of how adult education and learning opportunities are provided, who is responsible for these arrangements, who will benefit from them, and to what end. Historical accounts found in the literature depict the evolutions in thinking about education and learning of adults by the so-called 'big actors' in education governance, like the World Bank, UNESCO, the OECD and the EU (see for instance, Holford \& Mohorčič Špolar, 2012; Jacobi, 2009). These studies usually begin with the identification of a value-laden policy concept like 'lifelong learning', and go back in history to depict how such concept has been differently signified over time by one or more intergovernmental organizations or national governments. At times, they juxtapose governmental powers, ideologies, or actions by single national and/or local governments (see, for instance, Branchadell, 2015; Milana \& McBain, 2014). As a whole this body of literature has brought to light conceptual and policy changes in the way of thinking about adult education and learning and how this has provoked normative, administrative and financial alterations in the provision of education and learning opportunities for adults in different localities.

\section{Comparing Policies by Different Actors, Either at a Certain Point in Time or from an Historical Perspective (Pattern 2)}

Horizontal studies included under this pattern adopt space as the primary unit of analysis and represent $40 \%$ of the data set under consideration. These studies have two main aims. On the one hand, they aspire to comprehend, explain, and critique similarities and differences in policy discourses, agendas and actions across geographical and/or geopolitical territories at local, national or international scales. On the other hand, they purposely use geographical and/or geopolitical lenses with the aim of focusing attention on, and debating, the complexity of national or international policy and their practical implications for adult education and learning (see, for instance, Storan, 2010). A growing number of investigations deliberately centre attention on political actors with international reach, as their secondary unit of analysis, examine changes in the governance of adult education and learning, 
assess the working of specific policy instruments, and debate possible implications for adult education and learning practices (see, for instance, Moosung, Tryggvi \& Na'im 2008; Panitsides, 2015; Rubenson, 2015; Németh, 2015; Easton \& Samples, 2015; Tuckett, 2015; Milana, 2012). At times the secondary unit of analysis is specific programs and/or international implementation plans to which national governments subscribe; programs and plans that are coordinated at continental or global scales under the aegis of intergovernmental organizations, yet implemented by public-private partnerships. Exemplary here is Education For All (EFA), a declaration that, adopted by UNESCO in Jomtien (1990), and reaffirmed in Dakar (2000), has turned into major implementation plans covering up to 2015 and beyond (e.g. The Post-2015 Development Agenda) (see, for instance, Goldstein, 2006). In short, these studies help us to better comprehend the complexity of global governance in adult education, and the interplay between local-global dynamics.

\section{Juxtaposing Policies by Intergovernmental Organizations with Those of Their Member States, and Assessing Convergence and/or Divergence (Pattern 3)}

Vertical studies comprised under this research pattern represent $26 \%$ of the data set and use system as their primary unit of analysis. Like in pattern 1, these studies acknowledge the role that intergovernmental organizations play in producing changes at normative, administrative and/or financial levels, but pay attention to how this is the result of the interplay between international, national and local systems of governance. A system refers to a number of things that are connected in dynamic ways to form a complex whole and that governs an organized society, through laws, norms, power and language. Hence, these studies aim at unpacking the dynamic elements that compose specific systems of governance, and investigate their effects on other systems of governance. Like a matryoshka doll, systems of governance are vertically nested, while the organized societies they govern are also interconnected.

For the most part, these studies appreciate that the documents intergovernmental organizations produce, the activities they coordinate (e.g., international conferences) or requests and inputs they address to member states are not isolated but rather dynamic elements that contribute to the global governance of adult education (see, for instance, Milana, 2012, 2015, 2016). For example, Rubenson and Nesbit (2011) examined the process of producing a national report for Canada, in preparation to the VI International Conference on Adult Education (CONFINTEA), upon request by UNESCO. They reviewed how the production process played out in their national context and juxtaposed the Canadian report with that of a few countries with similar participation rates in adult education (i.e. Finland, Sweden and the United Kingdom).

Several studies also take a point of departure in a political notion introduced and/or sustained by the OECD or the EU, among others, and investigate how it is concretized within specific national contexts, often by juxtaposing two or more national systems (see, for instance, Plant \& Turner, 2005; Pohl \& Walther, 2007; 
Cavaco, Lafont, \& Pariat, 2014; Papastamatis \& Panitsidou, 2009). For example, Pohl and Walther (2007) examined policy developments within the European Union to explore the notion of 'activation of disadvantaged groups'. They discuss different activation models in place across selected member states, and pinpoint different activation mechanisms in education, training and the labor market.

Overall the studies under this research pattern have contributed new knowledge on the rise (and fall) of political notions and their concretizations in terms of new educational models, services or provisions. Moreover, they have contributed to our understandings of the impact that global policy-relevant activities have had or may have at either national or continental scales.

\section{Questioning and Countering Widespread Political Beliefs (Pattern 4)}

A fourth pattern was identified to collate all those contributions (14\% of the total work under consideration) for which it was not possible to identify a primary unit of analysis. These contributions aim at countering dominant political beliefs concerned with adult education and learning, and at problematizing the social imaginary it produces as the only way of making sense of society and its practices. A few clarifications are needed here. First, political beliefs cannot be used as a unit of analysis, as most academic work that falls under this pattern is not empirical in nature and most of these contributions can be catalogued as think pieces or discussion papers which scrutinize political beliefs and claims in policy. For instance, Ahmed (2010) looks at the policy claims that have increased since the 2009 global financial crisis that undertaking new educational actions in support of lifelong learning will offset the effects of the crisis, support sustainable development and help in the global fight against poverty.

A different yet common political belief is that lifelong learning promotes a country's development, independently from its geopolitical positioning in the world system. By adoption of a postcolonial perspective, and building on available evidence from Africa, Preece (2009) challenges this and demonstrates how the Global North sets learning priorities for the South and therefore reduces lifelong learning to basic education. Further contributions falling under this pattern problematize specific policy priorities at national, regional and global scales for which there is still limited evidence, and assess the impact of neoliberal policy, for instance on adult educators (Bowl, 2014), or on the social inclusion of vulnerable adults (De Greef, Verté, \& Segers, 2012). This body of work may not necessarily contribute novel knowledge to comprehend change and continuities in adult education policy or practice, but it helps preserve a space for subverting commonly held policy beliefs about adult education.

Table 3.1 outlines a summary of the findings in relation to the main units of analysis used in comparative policy research on adult education, as well as the strengths and weaknesses, which characterize each of the patterns described above. 
Table 3.1. Comparison of the four research patterns found in comparative and global policy studies on adult education and learning

\begin{tabular}{|c|c|c|c|c|}
\hline Pattern & Unit & Aim & Strengths & Weaknesses \\
\hline $\begin{array}{l}\text { No. } 1 \\
\text { Diachronic/ } \\
\text { Historical } \\
\text { accounts }\end{array}$ & Time & $\begin{array}{l}\text { Comprehend, } \\
\text { explain, and } \\
\text { critique changes } \\
\text { in ideologies over } \\
\text { time }\end{array}$ & $\begin{array}{l}\text { Policy evolutions (or } \\
\text { involutions). } \\
\text { External factors' } \\
\text { impact on normative, } \\
\text { administrative and } \\
\text { financial aspects }\end{array}$ & $\begin{array}{l}\text { Limited attention to } \\
\text { internal factors and } \\
\text { dynamics that also } \\
\text { affect provision }\end{array}$ \\
\hline $\begin{array}{l}\text { No. } 2 \\
\text { Horizontal } \\
\text { comparisons }\end{array}$ & Space & $\begin{array}{l}\text { Comprehend, } \\
\text { explain, } \\
\text { and critique } \\
\text { differences at } \\
\text { local, national } \\
\text { or international } \\
\text { scales }\end{array}$ & $\begin{array}{l}\text { Complexity of global } \\
\text { governance in adult } \\
\text { education } \\
\text { Interplay of } \\
\text { local-global dynamics }\end{array}$ & $\begin{array}{l}\text { Lack of attention } \\
\text { to intra-national } \\
\text { dynamics: } \\
\text { a) among different } \\
\text { institutional layers } \\
\text { and b) between } \\
\text { state, market and } \\
\text { civil society }\end{array}$ \\
\hline No. 3 & System & $\begin{array}{l}\text { Unpack the } \\
\text { dynamic } \\
\text { elements of } \\
\text { specific systems } \\
\text { of governance, } \\
\text { and investigate } \\
\text { their effects on } \\
\text { other systems of } \\
\text { governance }\end{array}$ & $\begin{array}{l}\text { Political notions and } \\
\text { their concretizations } \\
\text { in terms of new } \\
\text { educational models, } \\
\text { services or provisions } \\
\text { Impact of global } \\
\text { policy-relevant events } \\
\text { at either national or } \\
\text { regional scales }\end{array}$ & $\begin{array}{l}\text { No attention to the } \\
\text { scaling up (from } \\
\text { local to global } \\
\text { scales) of dynamic } \\
\text { connections and } \\
\text { effects }\end{array}$ \\
\hline No. 4 & $\begin{array}{l}\text { Political } \\
\text { beliefs }\end{array}$ & $\begin{array}{l}\text { Provide counter- } \\
\text { evidence to a } \\
\text { political belief to } \\
\text { problematize the } \\
\text { social imaginary } \\
\text { it produces }\end{array}$ & $\begin{array}{l}\text { Space for subverting } \\
\text { the viewpoints } \\
\text { Open up for new } \\
\text { research questions }\end{array}$ & $\begin{array}{l}\text { Does not produce } \\
\text { new empirical data }\end{array}$ \\
\hline
\end{tabular}

\section{CONCLUSION}

Summing up, different patterns in comparative and global policy studies contribute different types of knowledge to adult education scholarship. Specifically, pattern 1 has given attention to policy evolutions (or involutions) within intergovernmental organizations, hence helped increasing understandings, among adult education scholars, of external factors that impinge on normative, administrative and financial alterations in the provision of education and learning opportunities for adults in different locales. But it has paid only a limited attention to internal factors such as within country power relations and other internal dynamics that also affect such provision. 
Pattern 2 has helped increasing understandings among adult education scholars, of the complexity of global governance in adult education, and the interplay between local-global dynamics. But it has likewise overlooked the potential for deeper investigations of within-country power relations and other internal dynamics, such as within-country relations between federal states, regions, suburbs, cities/towns, and neighborhoods (as relevant by country), as well as by state, market and civil society.

Pattern 3 has contributed new knowledge to adult education research on the rise (and fall) of political notions that govern adult education, and their concretization in terms of new educational models, services or provisions. Besides, they have contributed to adult education scholars' understandings of the impact that global policy-relevant events have had or may have at either national or regional scales. Unfortunately, research following this pattern has not yet explored the potentials of exploring the scaling up (from local to global scales) of dynamic connections among different systems of governance, and their effects. This could be done, for instance, by placing attention on a country and then examine whether, and if so to what extent, local and national systems of governance may influence the working of more complex systems (e.g. the EU), or exploit policy-relevant events with a global reach (e.g., hosting CONFINTEA) for internal political gains, etc.

Last but not least, pattern 4 has helped adult education scholars to preserve a space for critiquing widespread political beliefs about the aim and value of adult education and learning through the adoption of novel perspectives to make available research evidence 'speak'. This, in turn, also raises new questions that deserve attention from researchers.

Taken together, all four research patterns reflect a collective effort by adult education researchers with an interest in policy developments to examine the changing power dynamics between international organizations, national governments and local communities. This is in line with a traditional concern of adult education scholars to understand the interactions between power over and power to in relation to people, and their communities. Yet, it recognizes that such communities have multiplied and expanded well beyond territorially bound polities. Therefore, assuming a multiscalar or global perspective in policy research provides a better opportunity for adult education scholars to acknowledge also non-territorially-bound political entities as exerting power over people, and their communities. However, especially pattern 4 opens up new opportunities to handing a different form of power to adult education scholars, and the academic and practice communities to which they belong and/or interact with. This is because it creates a space for individuals and collectives to exploit available research and knowledge to develop counter-narratives to taken-for-granted assumptions that are mostly based on partial or inaccurate analysis. Moreover, it allows for asking different sets of questions in the interrogation of available data, hence to bring to the fore evidence that otherwise would pass unnoticed in mainstream political debates about the education and learning of adults. This body of work may not necessarily contribute novel knowledge to comprehend change and continuities 
in adult education policy or practice, but it helps to preserve a space for subverting commonly held policy beliefs about adult education.

What can this research achieve when dominant neoliberal discourse, based on a competitive market approach, positions adult education as any other good that provide utility in a global market? Research that falls under patterns 1-3 can shed additional light not only on the pervasiveness of the dominant neoliberal discourse and its effects on adult education, but also on its cracks as well as on different forms of 'resistance' (Hollander \& Einwohner, 2004). Moreover, such knowledge can be appropriated by adult education scholars to further nurture pattern 4 , thus to problematize taken-for-grant policy beliefs on adult education. So, providing counter-evidence to erroneous or limited political beliefs on adult education constitutes a political space for adult education scholars to use research of policy to actually stimulate change in policy thinking and new social imaginaries in adult education.

\section{NOTE}

1 This chapter draws on the results of a meta-investigation first presented in Milana (2018).

\section{REFERENCES}

Ahmed, M. (2010). Economic dimensions of sustainable development, the fight against poverty and educational responses. International Review of Education, 56(2-3), 235-253.

Bartlett, W., Rees, T. L., \& Watts, A. G. (2000). Adult guidance services and the learning society: Emerging policies in the European Union. Bristol: Policy Press.

Bowl, M. (2014). Adult education in changing times: Policies, philosophies and professionalism. Leicester: National Institute of Adult Continuing Education.

Branchadell, A. (2015). Language education for adult migrants in Catalonia: Nation-state ambitions without nation-state resources. In J. Simpson \& A. Whiteside (Eds.), Adult language education and migration: Challenging agendas in policy and practice (pp. 82-93). London \& New York, NY: Routledge.

Cavaco, C., Lafont, P., \& Pariat, M. (2014). Policies of adult education in Portugal and France: The European agenda of validation of non-formal and informal learning. International Journal of Lifelong Education, 33(3), 343-361.

Corry, O. (2010). What is a (global) polity? Review of International Studies, 36(S1), 157-180.

de Greef, M., Verte, D., \& Segers, M. (2012). Evaluation of the outcome of lifelong learning programmes for social inclusion: A phenomenographic research. International Journal of Lifelong Education, 31(4), 453-476.

Desjardins, R., \& Rubenson, K. (2009). Research of vs research for education policy: In an era of transnational policy-making. Saarbrucken: VDM Verlag.

Easton, P., \& Samples, M. (2015). Adult Education at the World Bank: Poor cousin or key stakeholder? In M. Milana \& T. Nesbit (Eds.), Global perspectives on adult education and learning policy (pp. 194-206). Basingstoke \& New York, NY: Palgrave Macmillan.

Fejes, A., \& Wildemeersch, D. (2015). Cartographies of research on adult education and learning.[Special issue]. European Journal for Research on the Education and Learning of Adults, 6(2), 97-101.

Goldstein, H. (2006). Education for all: The globalization of learning targets. In L. Tett, M. Hamilton, \& Y. Hillier (Eds.), Adult literacy, numeracy and language: policy, practice and research (pp. 121-130). Maidenhead: Open University Press. 


\section{MILANA}

Gramsci, A. (1975). Quaderni dal Carcere (edizione critica a cura di V. Gerratana, 4 Voll). Torino: Einaudi. [Engl. Trans. (1971), Selections from the Prison Notebooks (Q. Hoare, \& G. Nowell Smith, Eds.). New York, NY: International Publishers]

Hinton-Smith, T. (2012). Widening participation in higher education casting the net wide? Basingstoke: Palgrave Macmillan.

Holford, J., \& Mohorčič Špolar, V. (2012). Neoliberal and inclusive themes in European lifelong learning policy. In S. Riddell, J. Markowitsch, \& E. Weedon, E. (Eds.), Lifelong learning in Europe equity and efficiency in the balance (pp. 39-61). Chicago, IL: Policy Press.

Hollander, J. A., \& Einwohner, R. L. (2004). Conceptualizing resistance. Sociological Forum, 19(4), 533-554.

Ioannidou, A. (2007). A comparative analysis of new governance instruments in the transnational educational space: A shift to knowledge-based instruments? European Educational Research Journal, $6(4), 336-347$.

Jacobi, A. (2009). International organizations and lifelong learning. Basingstoke \& New York, NY: Palgrave Macmillan.

Knox, A. B., Conceição, S. C. O., \& Martin, L. G. (2017). Mapping the field of adult and continuing education: An international compendium. Sterling, VA: Stylus Publishing.

Marginson, S. (1997). Markets in education. St. Leonards: Allen \& Unwin.

Milana, M. (2012). Political globalization and the shift from adult education to lifelong learning. European Journal for Research on the Education and Learning of Adults, 3(2), 103-117.

Milana, M. (2013). Globalisation, transnational policies and adult education. International Review of Education, 58, 777-797.

Milana, M. (2015). Debating global polity, policy crossing and adult education. Comparative Education Review, 59(3), 498-522.

Milana, M. (2016). Global polity in adult education and UNESCO: Landmarking, brokering, and framing policy. Globalisation, Societies and Education, 14(2), 203-226.

Milana, M. (2017). Global networks, local actions: Rethinking adult education policy in the 21st century. Abingdon \& New York, NY: Routledge.

Milana, M. (2018). Research patterns in comparative and global policy studies on adult education. In M. Milana, S. Webb, J. Holford, R. Waller, \& P. Jarvis (Eds.), The Palgrave international handbook on adult and lifelong education and learning (pp. 421-444). Basingstoke, HPH; New York, NY: Palgrave Macmillan.

Milana, M., \& Holford, J. (Eds.). (2014). Adult education policy and the European Union: Theoretical and methodological perspectives. Rotterdam, The Netherlands: Sense Publishers.

Milana, M., Holford, J., \& Mohorčič Špolar, V. (Eds.). (2016). Adult and lifelong education: Global, national and local perspectives. London: Routledge.

Milana, M., \& Klatt, G. (forthcoming). Governing adult education policy development in Europe: A critical appraisal of the renewed agenda for adult learning. In S. McGrath, M. Mulder, J. Papier, \& R. Suart (Eds.), International handbook of vocational education and training - Developments in the changing world of work. Cham: Springer.

Milana, M., \& McBain, L. (2014). Adult education in the United States of America: A critical examination of national policy (1998-2014). Encyclopaideia, 18(40), 34-52.

Milana, M., \& Nesbit, T. (Eds.). (2015). Global perspectives on adult education and learning policy. Basingstoke \& New York, NY: Palgrave Macmillan.

Milana, M., Webb, S., Holford, J, Waller, R., \& Jarvis, P. (Eds.). (2018). The Palgrave international handbook on adult and lifelong education and learning. Basingstoke \& New York, NY: Palgrave Macmillan.

Moosung, L., Tryggvi, T., \& Na'im, M. (2008). The evolution of the European Union's lifelong learning policies: An institutional learning perspective. Comparative Education, 44, 445-463.

Németh, B. (2015). Lifelong learning for all adults? A new concept for the United Nations Educational, Scientific and Cultural Organization - Limits and opportunities for a changing intergovernmental organization. In M. Milana \& T. Nesbit (Eds.), Global perspectives on adult education and learning policy (pp. 165-178). Basingstoke \& New York, NY: Palgrave Macmillan. 
Nesbit, T., \& Welton, M. (Eds.). (2013). Adult education and learning in a precarious age: The Hamburg Declaration revisited. San Francisco, CA: Jossey-Bass.

Nylander, E., \& Fejes, A. (Eds.). (2019). Mapping out the research field of adult education and learning (Lifelong learning series). Cham: Springer.

Panitsides, E. A. (2015). Towards "utilitarian" adult education perspectives? A critical review of the European Union adult education policy development. In M. Milana \& T. Nesbit (Eds.), Global perspectives on adult education and learning policy (pp. 207-220). Basingstoke \& New York, NY: Palgrave Macmillan.

Papastamatis, A., \& Panitsidou, E. (2009). The aspect of 'accessibility' in the light of European lifelong learning strategies: Adult education centres-a case study. International Journal of Lifelong Education, 28(3), 335-351.

Plant, P., \& Turner, B. (2005). Getting closer: Workplace guidance for lifelong learning. International Journal of Lifelong Education, 24(2), 123-135.

Pohl, A., \& Walther, A. (2007). Activating the disadvantaged. Variations in addressing youth transitions across Europe. International Journal of Lifelong Education, 26(5), 533-553.

Polkinghorne, D. (1983). Methodology for the human sciences: Systems of inquiry. Albany, NY: State University of New York Press.

Preece, J. (2009). Lifelong learning and development: A perspective from the 'South'. Compare, 39(5), $585-599$.

Rubenson, K. (2015). Framing the adult learning and education policy discourse: The role of the Organization for Economic Co-operation and Development. In M. Milana \& T. Nesbit (Eds.), Global perspectives on adult education and learning policy (pp. 179-193). Basingstoke \& New York, NY: Palgrave Macmillan.

Rubenson, K., \& Nesbit, T. (2011). CONFINTEA VI from a Canadian perspective. International Review of Education, 57(1-2), 127-143.

Sandelowski, M., \& Barroso, J. (2007). Handbook for synthesizing qualitative research. New York, NY: Springer Publishing Company.

Storan, J. (2010). Government's regional policy and its shaping of widening participation practice in England. In N. Longworth \& M. Osborne (Eds.), Perspectives on learning cities and regions: Policy, practice, and participation (pp. 307-322). Leicester: National Institute of Adult Continuing Education.

Schwandt, T. A. (2001). Dictionary of qualitative inquiry. Thousand Oaks, CA: Sage Publications.

Tett, L. (2014). Comparative performance measures, globalising strategies and literacy policy in Scotland. Globalisation, Societies and Education, 12(1), 127-142.

Tuckett, A. (2015). The international council for adult education and adult learning policy: Addressing the gap between rhetoric and practice. In M. Milana \& T. Nesbit (Eds.), Global perspectives on adult education and learning policy (pp. 221-236). Basingstoke \& New York, NY: Palgrave Macmillan.

Waller, R., Holford, J., Jarvis, P., Milana, M., \& Webb, S. (2015). Neo-liberalism and the shifting discourse of 'educational fairness'. International Journal of Lifelong Education, 34(6), 619-622.

Waller, R., Holford, J., Jarvis, P., Milana, M., \& Webb, S. (2014). Widening participation, social mobility and the role of universities in a globalized world. International Journal of Lifelong Education, 33(6), $701-704$. 